\title{
HUBUNGAN PENGETAHUAN IBU BALITA DENGAN MOTIVASI MEMBERI MAKANAN BERGIZI DI DESA PANAONGAN KECAMATAN PASONGSONGAN
}

\author{
Iva Gamar Dian Pratiwi, Program Studi Kebidanan UNIJA Sumenep \\ e-mail: kura_15587@yahoo.com \\ Nur Azifa, Program Studi Kebidanan UNIJA Sumenep \\ e-mail: kebidanan.fik@gmail.com
}

\begin{abstract}
ABSTRAK
The National Target stipulates that the coverage target of underweight children weighs in the weighted appeal of $80 \%$ but in fact the coverage of underweight who weighs in the appeal weighed in Panongan Village is $56.91 \%$ of the $80 \%$ target in 2014. The purpose of this study is to know the relationship of knowledge with the mother's motivation in providing nutritious food.

The research method used is analytic and research design that used is cross secsional, population in this research is all mother having toddler with amount of 298 people and taken sample171 people. By using stratified proportional random sampling technique, independent variable of mother's knowledge, dependent variable of mother's motivation in giving nutritious food, collecting data used in the form of questionnaire and using spearman test with degree of significance $\alpha=$ 0,05 .

The results showed that almost half (49.8\%) ie 85 people have less knowledge and almost half (49.8\%) of 85 people have a weak motivation.

The result of spearman test analysis shows the value $(\rho)=0.000$ and $(\alpha)=0,05$ thus $\rho<\alpha$ so Ho rejected means there is relation between knowledge with mother motivation in giving nutritious food. It is hoped that health workers will increase the extension to mothers so that the mother's knowledge will increase and the mother's motivation to have the toddler gives higher nutritious food to improve the good growth for her toddler.

Keywword:
\end{abstract}

\section{LATAR BELAKANG}

Negara Indonesia merupakan suatu Negara yang sedang melakukan pembenahan di segala bidang, yang tidak kalah pentingnya adalah pada bidang kesehatan. Satu dari sekian banyak indicator kesehatan yang dinilai dalam MDG's adalah kesehatan balita. Sesuai hasil PSG pada tahun 2014, Angka yang dicapai jawa timur telah di bawah ketentuan MDGs yaitu 15,5\%, Target MDGs 70\% pada tahun 2013.

Tinggi Badan, usia, dan BB merupakan status gizi yang digambarkan dalam bentuk 3 antopometri yaitu BB/TB, TB/U, BB/U. Jumlah kasus gizi burukterus mengalami penigkatan di daerah jawa timur pada tahun 2010 sampai 2012,yaitu 7760 pad 20110 hingga mencapai 11.056 pada tahun 2012. Hasil cakupan gizi di Kabupaten Sumenep tahun 2014 gizi buruk 8,5\%, gizi kurang $20,9 \%$, gizi baik $67,8 \%$, lebih gizi $2,8 \%$. Diantaranya $40 \%$ di sebabkan faktor kesalahan pemberian asupan, kemiskinan $28 \%$ dan penyakit bawaan $25 \%$.
Tabel 1.1 Sumber data Desa Panaongan berdasarkan Data hasil pencapaian Gizi di Desa Panaongan Kecamatan Pasongsongan Kabupaten Sumenep Tahun 2015.

\begin{tabular}{lcccc}
\hline \multicolumn{1}{c}{ Bulan } & $\begin{array}{c}\sum \\
\text { Balita }\end{array}$ & $\begin{array}{c}\sum \text { Ditimbang } \\
\text { Ditima }\end{array}$ & $\begin{array}{c}\sum \text { BB } \\
\text { Balita } \\
\text { naik }\end{array}$ & Pencapaian \\
\hline Januari & 298 & 90 & 47 & $52,20 \%$ \\
Februari & 298 & 284 & 216 & $76,00 \%$ \\
Maret & 298 & 291 & 154 & $52,90 \%$ \\
April & 298 & 293 & 96 & $32,70 \%$ \\
Mei & 298 & 288 & 181 & $62,80 \%$ \\
Juni & 298 & 291 & 188 & $64,60 \%$ \\
Juli & 298 & 291 & 189 & $64,90 \%$ \\
Agustus & 298 & 274 & 141 & $51,50 \%$ \\
September & 298 & 278 & 168 & $60,40 \%$ \\
Oktober & 298 & 279 & 153 & $54,80 \%$ \\
November & 298 & 277 & 161 & $58,10 \%$ \\
Desember & 298 & 263 & 137 & $52,00 \%$ \\
\hline Rata-rata & 298 & 3.199 & 1.831 & $56,91 \%$ \\
\hline Sumber & & &
\end{tabular}

Sumber : Desa Panaongan Tahun 2015 Kecamatan Pasongsongan Kabupaten Sumenep Sesuai dengan apa yang telah di jelaskan diatas maka balita yang timbangannya naik tiap bulan 
masih kurang memenuhi target. Target cakupan balita yang naik timbangannya di banding yang ditimbang menurut Dinas Kesehatan Sumenep adalah $80 \%$. Namun kenyataannya di Puskesmas Pembantu Panaongan persentase jumlah balita yang naik timbangannya di banding balita yang di timbang rata-rata perbulan masih $56,91 \%$

\section{Rumusan Masalah}

Berdasarkan latar belakang di atas maka rumusan masalah adalah "Adakah hubungan pengetahuan ibu balita dengan motivasi memberi makanan bergizi di wilayah kerja Desa Panaongan Kecamatan Pasongsongan Kabupaten Sumenep Tahun 2015? “.

Tujuan Penelitian

Untuk mengetahui hubungan pengetahuan ibu balita dengan motivasi memberi makanan bergizi di wilayah kerja Desa Panaongan Kecamatan Pasongsongan Kabupaten Sumenep Tahun 2015.

\section{METODE PENELITIAN}

Desain digunakan dalam penelitian ini yaitu Analitic correlational. Populasi yang digunakan adalah seluruh ibu yang memiliki anak di usia balita di Desa Panaongan yaitu 298 orang, sedangkan sampel nya adalah sebagian dari ibu yang memiliki balita yaitu sebanyak 171 orang. Tekhnik sampling nya adalah stratified proportional sampling dan mengguakan analisa data uji Spearman. Lokasi penelitian di Desa Panaongan Kecamatan Pasongsongan.

\section{HASIL PENELITIAN}

\section{A. Data Umum}

1) Umur

Tabel 1 Distribusi Frekuensi Berdasarkan Usia ibu di Desa Panaongan Tahun 2015

\begin{tabular}{cccc}
\multirow{2}{*}{ No } & \multirow{2}{*}{ Usia } & \multicolumn{2}{c}{ Responden } \\
\cline { 3 - 4 } & & F & $\%$ \\
\hline 1 & $17-19$ & 19 & 11,1 \\
2 & $20-22$ & 7 & 4,1 \\
3 & $23-25$ & 22 & 12,9 \\
4 & $26-28$ & 20 & 11,7 \\
5 & $29-31$ & 33 & 19,3 \\
6 & $32-34$ & 12 & 7 \\
7 & $35-37$ & 34 & 19,9 \\
8 & $38-40$ & 24 & 14 \\
\hline \multicolumn{2}{c}{ Jumlah } & 171 & 100 \\
\hline
\end{tabular}

Sesuai tabel 1 di atas, dapat di ketahui yaitu sebagian kecil $(19,9 \%)$ yaitu 34 orang ibu berusia 35-37 tahun.

2) Pendidikan

Tabel 2 Distribusi Frekuensi Berdasarkan Pendidikanh ibu di Desa Panaongan Tahun 2015

\begin{tabular}{cccc}
\hline \multirow{2}{*}{ No } & \multirow{2}{*}{ Pendidikan } & \multicolumn{2}{c}{ Responden } \\
& & F & $\%$ \\
\hline 1 & SD & 84 & 49,1 \\
2 & SMP & 51 & 29,8 \\
3 & SMA & 25 & 14,6 \\
4 & PT & 11 & 6,4 \\
\hline \multicolumn{2}{c}{ Jumlah } & 171 & 100 \\
\hline Berdasarkan
\end{tabular}

ketahui bahwa hampir setengahnya $(49,1 \%)$ yaitu 84 orang ibu perpendidikan SD .

3) Pekerjaan

Tabel 3 Distribusi Frekuensi Berdasarkan Pekerjaan ibu di Desa Panaongan Tahun 2015

\begin{tabular}{cccc}
\hline \multirow{2}{*}{ No } & \multirow{2}{*}{ Pekerjaan } & \multicolumn{2}{c}{ Responden } \\
& & $\mathrm{F}$ & $\%$ \\
\hline 1 & Tidak Bekerja & 34 & 19,9 \\
2 & Petani & 88 & 51,5 \\
3 & Swasta & 41 & 24 \\
4 & PNS & 8 & 4,7 \\
\hline & Jumlah & 171 & 100
\end{tabular}

Berdasarkan tabel 3 di atas, dapat di ketahui bahwa sebagian besar $(51,5 \%)$ yaitu 88 orang ibu berpekerjaan petani.

\section{B. Data Khusus}

1) Pengetahuan Ibu balita

Tabel 4 Distribusi Frekuensi Berdasarkan Pengetahuan ibu tentang makanan bergizi di Desa Panaongan Tahun 2015

\begin{tabular}{cccc}
\hline No & Pengetahuan & F & $\%$ \\
\hline 1 & Baik & 50 & 29,2 \\
2 & Cukup & 36 & 21,1 \\
3 & Kurang & 85 & 49,7 \\
\hline & Jumlah & 171 & 100 \\
\hline
\end{tabular}

Berdasarkan tabel 4 di atas, dapat di ketahui bahwa hampir setengahnya $(49,7 \%)$ yaitu 85 orang mempunyai pengetahuan kurang.

2) Motivasi ibu balita

Tabel 5 Distribusi Frekuensi Berdasarkan Motivasi ibu tentang makanan bergizi di Desa Panaongan Tahun 2015 


\begin{tabular}{cccc}
\hline No & Motivasi ibu & F & $\%$ \\
\hline 1 & Motivasi kuat & 36 & 21,1 \\
2 & Motivasi sedang & 50 & 29,2 \\
3 & Motivasi lemah & 85 & 49,7 \\
\hline & Jumlah & 171 & 100 \\
\hline
\end{tabular}

Berdasarkan tabel 5 di atas, dapat di ketahui bahwa hampir setengahnya $(49,7 \%)$ yaitu 85 orang mempunyai motivasi lemah.

3) Analisa Hubungan Antara Ibu Balita Dengan Motivasi Memberi Makanan Bergizi

Tabel 6 Tabulasi Silang Pengetahuan Ibu Dengan Motivasi Ibu Dalam Memberikan makanan bergizi Di Desa Panaongan Kecamatan Pasongsongan Kabupaten Sumenep Tahun 2015

\begin{tabular}{ccccccccc}
\hline \multirow{2}{*}{$\begin{array}{c}\text { Pengetahuan } \\
\text { Ibu }\end{array}$} & \multicolumn{9}{c}{ Kuat } & \multicolumn{2}{c}{ Sedivasi Ibu } & \multicolumn{2}{c}{ Jumlah } \\
\cline { 2 - 7 } & $\mathbf{N}$ & $\mathbf{\%}$ & $\mathbf{N}$ & $\mathbf{\%}$ & $\mathbf{N}$ & $\mathbf{\%}$ & N & \% \\
\hline Baik & 36 & 72 & 14 & 28 & 0 & 0 & 50 & 100 \\
Cukup & 0 & 0 & 36 & 100 & 0 & 0 & 36 & 100 \\
Kurang & 0 & 0 & 0 & 0 & 85 & 100 & 85 & 100 \\
Jumlah & 63 & 37 & 50 & 29,2 & 85 & 49,8 & 171 & 100
\end{tabular}

Sumber data : Data primer

Data diatas menunjukkan bahwa, dari 50 responden yang mempunyai pengetahuan Baik sebagian besar $(72 \%)$ yaitu 36 responden. Di Desa Panaongan mempunyai motivasi yang kuat untuk memberi makanan bergizi pada balita, dan dari 36 responden yang mempunyai pengetahuan cukup seluruhnya (100\%) yaitu 36 responden di Desa Panaongan mempunyai motivasi sedang untuk memberi makanan bergizi pada balita, dan dari 85 responden yang mempunyai pengetahuan kurang Seluruhnya (100\%) yaitu 85 responden Di Panaongan mempunyai motivasi yang lemah untuk memberi makanan bergizi pada balita.

Dari tabel tersebut, kemudian di analisis dengan uji Spearman. Didapatkan bahwa nilai sig 0,000 dengan derajat kemaknaan 0.05 sehingga kurang dari $\alpha(\rho<\alpha)$., yaitu $\mathrm{H} 1$ diterima bahwa ada hubungan pengetahuan dengan motivasi ibu dalam memberikan makanan bergizi di Desa Panaongan Kecamatan Pasongsongan Kabupaten Sumenep tahun 2015.

\section{PEMBAHASAN}

\section{a. Pengetahuan Ibu Dalam Memberi Makanan Bergizi}

Berdasarkan Hasil Penelitian Yang dilakukan di Desa Panaongan, diketahui dari tabel 4 menyatakana bahwa dari 171 responden hampir setengahnya $(49,7 \%)$ yaitu 85 orang mempunyai pengetahuan kurang. Pengetahuan adalah hasil "tahu" dari manusia, yang terjadi sesudah seseorang melaukan

pengenalan terhadap suatu hal tertentu.Pengetahuan ini terjadi melalui media panca indera yang dimiliki manusia. Ada beberapa hal yang mempengaruhi pengetahuan ini, yakni faktor dari dalam da luar.. Faktor internal meliputi umur, pendidikan, pekerjaan (Notoatmodjo, 2005).

1. Umur Ibu

Berdasarkan hasil crosstabs lampiran 12 menunjukkan pada semua kelompok umur ibu dominan mempunyai pengetahuan yang kurang, dimana pada kelompok umur 26-28 tahun mempunyai persentase yang tinggi. Usia yang semakin tua akan berdampak pada cara berfikir dan memotivasi untuk melakukan pemberian makanan bergizi. Pada usia tersebut seseorang mampu menerima informasi dengan baik, sehingga seorang ibu yang memiliki usia agak tua akan berpikir lebih masuk akal dan dewasa tentang pentingnya pemberian makanan bergiizi

2. Pendidikan Ibu

$$
\text { Berdasarkan hasil crosstabs }
$$

lampiran 12 menunjukkan pada semua kelompok pendidikan ibu dominan mempunyai pengetahuan yang kurang, dimana pada kelompok SMA mempunyai persentase yang tinggi. Semakin tinggi tingkat pendidikan ibu dan di dukung oleh usia yang produktif maka semakin mudah pula menerima informasi, selain itu keluarga dapat mencari informasi dari media massa ataupun dari media elektronik, sehingga peengetahuaan keluarga meningkat dan mengetahui pentingnya pemberian 
makanan bergizi. $\mathrm{b}$

Hal ini sesuai dengan pernyataan Notoatmodjo (2005) bahwa pendidikan berpengaruh pada proses belajar, yakni semakin tinggi seseorang menimba ilmu maka semakin mudah orang tersebut menerima informasi. Yang harus di garis bawahi adalah bahwa seseoran yang memiliki tingkat pendidikan rendah belumtentu memiliki pengetahuan yang rendah pula, karena pendidikan bisa dilakukan diluar sekolah atau pendidikan non formal.

\section{Pekerjaan Ibu}

Berdasarkan hasil crosstabs lampiran 12 menunjukkan pada semua kelompok pekerjaan ibu dominan mempunyai pengetahuan yang kurang, dimana pada kelompok petani mempunyai persentase yang tinggi. Menurut Kabir (2005). Seorang wanita yang bekerja akan lebih bisa memanfaatkan pelayanan kesehatan daripada seorang perempuan yang berprofesi sebagai ibu rumah tangga. Seorang wanita bekerja akan lebih memiliki banyak informasi dan berpotensial memiliki tiingkat pengetahuan lebih tinggi, sehingga akan sangat mempengaruhi ibu dalam melakukan pemberian makanan bergizi.

Di lapangan didapatkan bahwa pengetahuan ibu yang rendah menyebabkan kurangnya informasi tentang pentingnya memberikan makanan bergizi pada balitanya, sehingga ibu memiliki perilaku yang tidak terlalu memperdulikan dalam melakukan pencegahan penyakit. Dengan demikian, pengetahuan merupakan salah satu faktor yang menjadi penentu lengkap atau tidaknya tersampainya informasi tentang makanan bergizi, karena seiring dengan tingginya pengetahuan ibu maka ibu tersebut akan mendapatkan informasi kesehatan yang lebih lengkap khususnya tentang kesehatan balita. Pemberian informasi kesehatan yang lengkap oleh tenaga kesehatan diharapkan dapat memberikan masukan bagi ibu untuk menambah wawasan ibu tentang pentingnya kesehatan balita.

\section{Motivasi Ibu Dalam Memberi Makanan Bergizi}

Berdasarkan Hasil penelitian yang dilakukan di Desa Panaongan, diketahui dari tabel 5 didaptakan bahwa hampir setengahnya
$(49,7 \%)$ yaitu 85 orang mempunyai motivasi lemah.

Motivasi terkadang diartikan oleh kebanyakan orang dengan maksud dorongan. Motivasi adalah suatu kekuatan dorongan yang akan membuat manusia bertingkah laku yang pada akhirnya akan memiliki maksud an tujuan tertentu. Adapun faktor-faktor yang mempengaruhi motivasi ibu adalah sebagai berikut:

\section{Umur Ibu}

$$
\text { Berdasarkan hasil crosstabs }
$$

lampiran 12 menunjukkan pada semua kelompok umur ibu dominan mempunyai motivasi lemah, dimana pada kelompok umur 26-28 tahun mempunyai persentase yang tinggi bermotivasi lemah. Semakin tua usia seseorang maka akan berpengaruh pada sikap seseorang dalam memutuskan sesuatu hal. Pada usia tersebut seseorang mampu menerima informasi dengan baik, sehingga sudah bisa memutuskan sesuatu hal dengan baik.

2. Pendidikan Ibu

Berdasarkan hasil crosstabs lampiran 12 menunjukkan pada semua kelompok pendidikan ibu dominan mempunyai motivasi lemah, dimana pada kelompok SMA mempunyai persentase yang tinggi bermotivasi lemah. Semakin tinggi tingkat pendidikan ibu dan di dukung oleh usia yang produktif maka semakin mudah pula menerima informasi, selain itu keluarga dapat mencari informasi dari media massa ataupun dari media elektronik, sehingga peengetahuaan keluarga meningkat dan mengetahui pentingnya pemberian makanan bergizi.

Hal ini sesuai dengan pernyataan Notoatmodjo (2005) bahwa pendidikan memiliki pengaruh terhadap sikap seseorang. Informasi yang diperlukan oleh seseorang kebanyakan akan diperoleh di saat seseorang menempuh tingkat pendidikan formal, sehingga jika tingkat pendidikan seseorang tinggi maka harapannya adalah pengetahuan yang didapatpun juga akan semakin banyak, akan tetapi tidak selamanya seseorang yang memiliki pendidikan rendah memiliki tingkat pengetahuan yang rendah pula, hal tersebut bisa terjadinya sebaliknya didalam masyarakat.karena pendidikan bisa dilakukan diluar sekolah atau pendidikan non formal.

3. Pekerjaan Ibu 
Berdasarkan hasil crosstabs lampiran 12 menunjukkan pada semua kelompok pekerjaan ibu dominan mempunyai motivasi lemah, dimana pada kelompok petani mempunyai persentase yang tinggi. Menurut Kabir (2005) seorang ibu rumah tangga belum bisa memanfaatkan pelayanan kesehatan dengan baik dibandingkan ibu yang bekerja, ibu yang bekerja cenderung memiliki pengetahuan yang lebih luas dengan informasi yang mereka dapat diluar, hal tersebut sangat mempengaruhi ibu dalam melakukan pemberian makanan bergizi.

Pada kenyataannya, dilapangan masih banyak ibu yang tidak memberikan makanan bergizi pada balitanya karena kurangnya pengetahuan ibu tentang manfaat makanan bergizi sehingga dapat mengganggu kesehatan balita.

\section{Hubungan Pengetahuan Dengan Motivasi Ibu Dalam Memberikan Makanan Bergizi}

Sesuai data diatas yaitu tabel 5.6 diatas menunjukkan bahwa, dari 50 responden yang mempunyai pengetahuan Baik sebagian besar (72\%) yaitu 36 responden Di Desa Panaongan mempunyai motivasi yang kuat untuk memberi makanan bergizi pada balita, dan dari 36 responden yang mempunyai pengetahuan cukup Seluruhnya (100\%) yaitu 36 responden di Desa Panaongan mempunyai motivasi sedang untuk memberi makanan bergizi pada balita, dan dari 85 responden yang mempunyai pengetahuan kurang Seluruhnya (100\%) yaitu 85 responden Di Panaongan mempunyai motivasi yang lemah untuk memberi makanan bergizi pada balita.

Hasil uji Spearman. Didapatkan bahwa nilai sig 0,000 dengan derajat kemaknaan 0.05 sehingga kurang dari $\alpha \quad(\rho<\alpha)$, sehingga hipotesa diterima yang berarti terdapat hubungan pengetahuan dengan motivasi ibu dalam memberikan makanan bergizi di Desa Panaongan Kecamatan Pasongsongan Kabupaten Sumenep.

Menurut Hafrida (2004, ada keterkaitan antara status gizi dengan pola asuh, semakin baik pola asuh yang diterapkan oleh keluarga, maka status gizi nya pun akan baik, karena dengan pola asuh yang baik maka keluarga akan berupaya untuk memenuhi kebutuhan gizi terbaik untuk anaknya.
Ketika keluarga dalam hal ini suami tidak mendukung ibu untuk memberikan makanan bergizi pada balitanya, maka ibu cenderung untuk tidak memberikan makanan bergizi dengan baik pada balitanya. Dalam hal ini keluarga tidak peduli ketika ada efek samping saat tidak memberi makanan berigizi, seperti: BB tidak naik dan badan kurus karena kurangnya makanan bergizi. Sehingga ibu tidak memberikan makanan bergizi pada balita yang

menimbulkan efek tersebut. Hal ini terlihat kebanyakan ibu tidak memberikan makanan bergizi menimbulkan BB tidak naik dan badan kurus. Untuk mengatasi hal tersebut diatas yaitu dengan meningkatkan pengetahuan masyarakat mengenai makanan bergizi melalui penyuluhan dan pemberian konseling makanan bergizi terutama mengenai manfaat makanan bergizi, melakukan koordinasi dengan kader dan masyarakat untuk menyusun jadwal posyandu yang tepat sehingga tidak memungkinkan adanya perubahan jadwal posyandu.

\section{KESIMPULAN}

\section{DAN SARAN}

\section{Kesimpulan}

a. Pengetahuan ibu tentang makanan bergizi di Desa Panaongan hampir setenghnya berpengetahuan kurang.

b. Motivasi ibu memberi makanan bergizi di Desa Panaongan hampir setengahnya mempunyai motivasi lemah memberi makanan bergizi.

c. Pengetahuan ibu balita dengan motivasi memberi makanan bergizi di Desa Panaongan Kecamatan Pasongsongan tahun 2014 mempunyai hubungan yang signifikan.

\section{Saran}

a. Bagi Peneliti Selanjutnya

Perlu di teliti lebih lanjut tentang faktor lain yang potensial berpengaruh dalam memberikan makanan bergizi, misalnya: faktor sosial budaya, tenaga kesehatan, dukungan petugas kesehatan sarana dan prasarana kesehatan, serta faktor lingkungan

b. Bagi peneliti

Di harapkan peneliti lebih mempelajari lagi tentang pengetahuan dengan motivasi 
ibu dalam memberikan makanan bergizi.

\section{DAFTAR PUSTAKA}

Aziz Alimul (2007). Metode Penelitian Penulisan Ilmiah. Jakarta : Salemba Medika.

Arikunto (2006). Prosedur Penelitian. Jakarta : Rineka Cipta

Depkes RI. (2004). Penilaian Gizi. http:// www.depkes RI.go.id. diakses pada tanggal 25 Maret 2015.

Manuaba I.B.G (2010), Ilmu Kebidanan untuk pendidikan bidan, Jakarta, Penerbit, Buku Kedokteran, EGC

Nursalam (2003). Konsep dan Penerapan Metodologi Penelitian Kebidanan. Jakarta : Salemba Medika.

Nursalam (2011). Konsep dan Penerapan Metodologi Peneitian Kebidanan. 